\title{
Analisis Maqashid Al-Syari'ah Dalam Keputusan Konsumen Memilih Hunian Islami Pada Perumahan Vila Ilhami Tangerang
}

\author{
Oleh: \\ Atiqi Chollisni \\ Kiki Damayanti
}
Sekolah Tinggi Ekonomi Syariah (STES) Islamic Village Tangerang Jl. Islamic Raya Kelapa Dua Tangerang-Banten

\begin{abstract}
This research aims to develop a theory of the role of the Maqashid al-Sharia as the basis for the decision of a Muslim consumers. It includes protecting religion (hifdzu-din), protecting the soul (hifdzunafs), protecting the mind (hifdzu-'aqI), protecting offspring (hifdzunasl), and protecting the property (hifdzu-mal). Muslim consumers have the advantage that they meet their needs not just to meet the individual needs (material), but also meet social needs (spiritual). In Islam, a Muslim consumer should reflect his relationship with God (hablu mina Allah) and man (hablu mina an-nas). This concept is not found in conventional consumer behavior. This research was conducted in the residential property industry that creates Islamic house concept. Islamic house concept is a residential concept based on sharia law. The research method used rating scale as a measure to determine the elements of the maqasid al-shariah were most responsible for Muslim consumer decisions. The results of this study indicate that the elements of the Maqasid al-Sharia is very important, especially from the element of protecting religion (hifdzu-din), then protecting the property (hifdzumal), and the last is to protecting offspring (hifdzu-nasl).
\end{abstract}

Keywords: Maqasid al-Sharia, Islamic house concept, muslim consumer decisions.

\section{Pendahuluan}

Minat konsumen dalam bidang jasa, sangat tinggi. Terutama kebutuhan untuk hunian atau tempat tinggal. Dalam segi skala bisnis, bisnis properti konvensional lebih memiliki kekuatan dan perkembangannya juga telah berlangsung dalam waktu yang cukup lama. Seperti yang terdapat pada iklan properti baik berupa perumahan atau perkantoran, maka akan sangat jarang ketika yang ditunjukkan adalah sarana-sarana beribadah. Akan lebih banyak ditemukan berupa fasilitas hiburan, olah raga atau fasilitas-fasilitas pendukung yang lain. 
Kesibukan dan rutinitas sering kali membuat manusia melalaikan dari nilai-nilai keyakinan. Padahal nilai-nilai keyakinan menjadi penting, bukan saja sebagai pegangan hidup, tetapi manusia pada hakikatnya tidak bisa dilepaskan dengan nilai-nilai keyakinan. Karena itu, saat ini mudah dijumpai kecenderungan masyarakat yang ingin kembali pada kehidupan agamis setelah sebelumnya dikesampingkan. Beberapa cara untuk mengembalikan dan menghadirkan kembali hal itu bisa dilakukan lewat komunitas di kawasan hunian.

Dalam permasalahan tersebut, terdapat pilihan pada konsep bisnis jasa perumahan, khususnya hunian yang bernuansa Islami. Salah satu contoh yaitu diciptakannya pemukiman muslim. Akhir-akhir ini banyak pengembang yang membangun kompleks perumahan baru dengan mengusung label Islami. Dalam bisnis hunian Islami, selain fasilitas pendukung yang dijadikan sarana penarik minat investor, juga sarana ibadah.

Sebagai negara berpenduduk muslim terbesar di dunia, Negara Indonesia termasuk negara dengan penyerapan budaya dan tradisi Islam sangat sedikit dalam konsep sebuah kawasan hunian. Konsep lingkungan tempat tinggal Islami sesungguhnya tidak sulit. Secara sederhana, konsep hunian Islami merupakan sebuah hunian dengan desain Islami, baik arsitekturnya maupun lingkungan kehidupannya. Di dalamnya terdapat simbol-simbol keislaman sekaligus tata pergaulan dan kehidupan Islami. Perumahan Islami secara konsepsi masih terbuka untuk dikaji secara mendalam. Karena tidak sebatas membangun perumahan menghadap kiblat atau tersedianya mesjid. Lebih dari itu, seluruh aktifitas yang kelak dilakukan warga yang mendiami perumahan ini harus diatur sesuai syariah.

Aspek lain yang perlu diperhatikan dan membedakan sebuah hunian berfondasi syari"ah Islam dengan perumahan konvensional pada umumnya, adalah manajemen dan struktur perusahaan melibatkan dewan pengawas dan penasihat syariah. Juga tidak kalah penting, adanya budaya senantiasa menerapkan nilai-nilai Islam dalam tata kelola perusahaan pengembang

Antusias masyarakat terhadap konsep transaksi kepemilikan rumah sesuai syariat Islam begitu besar. Hal ini terbukti dengan bertambahnya peminat dari tiap proyek properti yang digarap oleh pengembang selalu tinggi. Konsep transaksi sesuai syariah dan konsep tanpa riba yang begitu menonjol, pengembang menegaskan diferensiasinya dengan pengembang lain dengan konsep konvensional. 


\section{Maqashid Al-Syari'ah}

Maqashid al-Syari"ah merupakan tujuan Allah dan Rasul-Nya dalam merumuskan hukum-hukum Islam. Tujuan itu dapat ditelusuri dalam ayat-ayat Al-Qur"an dan Sunnah Rasulullah sebagai alasan logis bagi rumusan suatu hukum yang berorientasi kepada kemashlahatan manusia.(Effendi, 2009:233)

Maslahah berasal dari kata Bahasa Arab yang berarti sesuatu yang mendatangkan kebaikan. Maslahah (kesejahteraan umum) yakni yang dimutlakkan. Menurut Imam Ar-Razi, maslahah adalah perbuatan yang telah ditujukan oleh syari" (Allah) kepada hamba-Nya demi memelihara dan menjaga agamanya, jiwanya, akalnya keturunannya dan harta bendanya. Secara etimologi maqashid al-syari"ah terdiri dari dua kata, yakni maqashid dan syari"ah. Maqashid adalah bentuk jamak dari maqshud yang berarti kesengajaan, atau tujuan. Adapun al-syari"ah artinya ajaran, aturan dan ketentuan Allah SWT kepada para hambanya untuk mencapai kesejahteraan dunia dan akhirat. (Mingka, 2013:38) Secara terminologi, beberapa pengertian tentang maqashid alsyari"ah yang dikemukakan oleh beberapa ulama terdahulu antara lain:

Menurut Al-Imam al-Ghazali, "Penjagaan terhadap maksud dan tujuan syari"ah adalah upaya mendasar untuk bertahan hidup, menahan faktor-faktor kerusakan dan mendorong terjadinya kesejahteraan."

Menurut Al-Imam al-Syathibi "Al-Maqashid terbagi menjadi dua: yang pertama, berkaitan dengan maksud Tuhan selaku pembuat syari"ah dan kedua, berkaitan dengan maksud mukallaf."

Maksud syar" $i$ (Allah) adalah kemashlahatan untuk hamba-Nya di dalam dua tempat; dunia dan akhirat. Dan maksud mukallaf (manusia) adalah ketika hamba-Nya dianjurkan untuk hidup dalam kemashlahatan di dunia dan akhirat. Yaitu dengan menghindari kerusakan- kerusakan yang ada di dalam dunia.

Menurut Shidiq (2010:206), Syariat Islam yang dibawa oleh Nabi Muhammad SAW merupakan rahmat untuk sekalian manusia. Firman Allah SWT yang memperkuat tentang kesempurnaan Islam tersebut diantaranya disebutkan dalam QS. Al-Anbiya 21: 107 Artinya: "dan Tiadalah Kami mengutus kamu, melainkan untuk (menjadi) rahmat bagi semesta alam"(QS.Al-Anbiya 21:107)

Atas dasar penegasan ayat di atas, syekh Muhammad Abu Zahra dalam kitabnya Ushul Fiqh merumuskan tiga tujuan kehadiran hukum Islam:

1. Membina setiap individu agar menjadi sumber kebaikan bagi orang lain, tidak menjadi sumber keburukan kepada orang lain. 
Untuk mencapainya adalah melalui ibadah yang telah disyariatkan seperti shalat, puasa, dan haji. Melalui shalat seorang mukmin menyayangi yang lain dan tidak berlaku zalim dan keji, sejalan dengan firman Allah SWT dalam QS. Al-Ankabut ayat 45 Demikian juga ibadah haji mengandung ajaran yang jelas tentang aturan berkumpul, hal yang sama juga terdapat pada ibadah zakat yang memiliki ajaran tolong menolong antara orang kaya dengan orang fakir.

2. Menegakkan keadilan dalam masyarakat baik sesama muslim maupun non muslim, firman Allah SWT dalam QS.Al-Maidah:8. Konsep keadilan dalam Islam menurut Abu Zahra adalah menempatkan manusia pada posisi yang sama di depan hukum. Tidak ada keistimewaan antara si kaya dan si miskin.

3. Meralisasikan kemashlahatan. Aspek ketiga ini merupakan tujuan puncak yang melekat pada hukum Islam secara keseluruhan. Maka tidak ada syari"at yang berdasarkan kepada al-Qur"an dan hadits kecuali didalamnya terdapat kemashlahatan yang hakiki dan berlaku umum.

\section{Unsur Maqashid Al-Syari'ah}

Dalam ruang lingkup tujuan syari"ah, para ulama merumuskan lima tujuan diturunkannya syari"ah Islam yang dikenal dengan maqashid al-syari"ah (maksud dan tujuan syari"ah). Kelima maqashid tersebut adalah: (Abdurrahman, 2014:12)

1. Menjaga agama (hifdzu-din) Sebagai bentuk penjagaan Islam terhadap agama (hifdzu-din), maka Allah SWT telah memerintahkan kepada hamba-hamba-Nya untuk beribadah. Diantara bentuk ibadah tersebut adalah shalat, zakat, puasa, haji, zikir, doa, dan lain-lain. Dengan menjalankan ibadah-ibadah itu, akan tegaklah din seseorang.

2. Menjaga jiwa (hifdzu-nafs) Islam melindungi seluruh umat manusia, maka dalam rangka menjaga keselamatan jiwa manusia dari pembunuhan tanpa alasan yang benar, Allah ta"ala mengharamkan membunuh manusia tanpa alasan yang dibenarkan oleh Islam. Jika terjadi sebuah pembunuhan, wajib atasnya ditegakkan qishas (QS. Al-Baqarah: 178). Selain larangan menghilangkan nyawa orang lain, Islam juga melarang seseorang utntuk melakukan bunuh diri. (QS. An-Nisaa":29)

3. Menjaga pikiran (hifdzu al-'aqI) Sebagai alasan diwajibkannya menuntut ilmu sepanjang hayat. Syariat Islam melarang khamr (minuman keras), narkotika dan obat terlarang, dan apa saja yang 
dapat merusak akal. Hal ini bertujuan menjaga akal manusia dari apa saja yang dapat mengganggu fungsinya. Islam memandang bahwa akal manusia adalah anugerah dan nikmat Allah yanng sangat besar. Dengan akal, manusia menjadi lebih mulia daripada makhluk-makhluk Allah lainnya. Untuk mensyukuri nikmat Allah tersebut, syariat mewajibkan seseorang untuk memelihara akalnya dari apa saja yang akan mengganggunya atau mengurangi fungsi kerjanya. Sesuai hadis Rasulullah $A b u$ Darda berkata: " $A k u$ mendengar Rasulullah Shallallahu „alaihi wasallam bersabda: "Barangsiapa menempuh jalan untuk mencari ilmu, maka Allah akan menuntunnya menuju surga dan para malaikat akan meletakkan sayap-sayapnya karena senang kepada pencari ilmu, sesungguhnya orang berilmu itu akan dimintakan ampunan oleh (makhluk) yang berada di langit dan di bumi hingga ikan di air, keutamaan orang yang berilmu atas ahli ibadah laksana keutamaan rembulan atas seluruh bintang (HR. Tirmidzi: 2606)

4. Menjaga keturunan (hifdzu-nasl) Sebagai alasan diwajibkannya memperbaiki kualitas keturunan, membina sikap mental generasi penerus agar terjalin rasa persahabatan diantara sesama umat manusia, dan diharamkannya zina serta perkawinan sedarah. Allah SWT menyifatkan zina sebagai suatu kekejian dan jalan yang buruk.

5. Menjaga harta (hifdzu-mal) Untuk memperoleh harta yang halal, syariat Islam membolehkan berbagai macam bentuk muamalah, seperti jual beli, sewa menyewa, gadai, dan lainnya. Untuk menjaganya, syariat Islam mengharamkan umatnya memakan harta manusia dengan jalan yang batil, seperti mencuri, riba, menipu, mengurangi timbangan, korupsi, dan lain-lain (QS. AnNisaa':29)

Dalam hal ini, Imam al-Ghazali berpendapat bahwa: "Sesungguhnya mengambil manfaat dan menolak mudharat adalah menjadi tujuan makhluk. Baik dan buruknya makhluk sangat tergantung sejauh mana tujuan makhluk tersebut telah berhasil dicapai. Namun yang dimaksud dengan kemashlahatan disini adalah memelihara tujuan syara". Tujuan syara" yang berhubungan dengan makhluk meliputi: menjaga agama, jiwa, akal, keturunan dan harta mereka. Setiap hal yang mengandung upaya menjaga lima perkara pokok tersebut adalah maslahat. Sebaliknya, setiap hal yang tidak mengandung lima perkara pokok tersebut adalah mafsadah." 
Imam al-Syathibi dalam kitab al-muwafaqat berkata "sekali-kali tidaklah syariat itu dibuat kecuali untuk merealisasikan manusia baik di dunia maupun di akhirat dan dalam rangka mencegah kemafsadatan yang akan menimpa mereka."

Tujuan umum dari syari"ah adalah untuk merealisasikan kemashlahatan hidup manusia dengan mendatangkan manfaat dan menghindari mudharat. Kemashlahatan yang menjadi tujuan hukum Islam adalah kemashlahatan yang hakiki yang berorientasi kepada terpeliharanya lima unsur yaitu agama, jiwa harta, akal, dan keturunan. Karena dengan kelima unsur inilah manusia dapat menjalankan kehidupannya yang mulia.(Zahra: 367 )

Menurut Imam Syathibi, kemashlahatan yang akan diwujudkan oleh syari"ah dari kelima unsur tersebut memiliki tiga peringkat kebutuhan yang terdiri dari kebutuhan dharuriyat, hajiyat, tahsiniyat. Syari"ah bertujuan untuk memelihara dan melestarikan kebutuhan manusia dalam semua peringkat.

Dharuriyat adalah memelihara kebutuhan-kebutuhan yang bersifat esensial (pokok) bagi kehidupan manusia. Kebutuhan yang esensial (pokok) itu meliputi agama, jiwa, akal, keturunan dan harta. Apabila tidak terpeliharanya kelima unsur tersebut dalam tingkat dharuriyat akan berakibat fatal, seperti terjadinya kehancuran, kerusakan, dan kebinasaan dalam hidup manusia baik di dunia maupun di akhirat. Kebutuhan dharuriyat merupakan kebutuhan yang paling utama dibanding dua mashlahat lainnya, yaitu hajiyat dan tahsiniyat.

Peringkat hajiyat tidak termasuk kepada suatu yang pokok dalam kehidupan melainkan termasuk kebutuhan yang dapat menghindarkan manusia dari kesulitan hidup. Jika peringkat hajiyat tidak terpenuhi maka tidak akan mengakibatkan kehancuran dan kemusnahan bagi kehidupan manusia sebagaimana tidak terpenuhinya kebutuhan dharuriyat tapi akan membawa kesulitan dan kesempitan. Peringkat hajiyat ini berkaitan erat dengan masalah rukhsoh (keringanan) dalam ilmu fiqh.

Peringkat tahsiniyat adalah kebutuhan yang menunjang peningkatan martabat hidup seseorang dalam masyarakat dan di hadapan Allah SWT sebatas kewajaran dan kepatuhan. Apabila kebutuhan tingkat ketiga ini tidak terpenuhi, maka tidak menimbulkan kemusnahan hidup manusia sebagaimana tidak terpenuhinya kebutuhan dharuriyat dan tidak akan membuat hidup manusia menjadi sulit sebagaimana tidak terpenuhinya kebutuhan hajiyat akan tetapi kehidupan manusia dipandang tidak layak menurut ukuran akal dan fitrah manusia. Perkara yang terkait dengan kebutuhan tahsiniyat ini terkait dengan akhlak mulia dan adat yang baik. 
Menurut Abdul Wahab Khallaf, jika tiga peringkat kebutuhan tersebut masing- masing dharuriyat, hajiyat, tahsiniyat telah dipenuhi secara sempurna maka kemashlahatan manusia yang merupakan tujuan hukum syariat dapat terealisasi.

\section{Hunian Islami}

Hunian dalam arti harfiah dapat diidentikkan dengan sosok „rumah" yang merupakan benda mati. Undang-Undang RI No.1 Tahun 2011 tentang Perumahan dan Kawasan Permukiman, bahwa rumah adalah bangunan gedung yang berfungsi sebagai tempat tinggal yang layak huni, sarana pembinaan keluarga, cerminan harkat dan martabat penghuninya, serta aset bagi pemiliknya. Menurut Zulrizka (2013:2) "Rumah merupakan tempat berbagi cerita, pengalaman, pengetahuan, dan lain-lain dari setiap anggota keluarga di rumah tersebut. Setiap anggota keluarga dituntut untuk aktif agar dapat terjadi pembinaan di dalam keluarga tersebut".

Menurut Abraham Maslow (2003) dalam teori Hierarchy of Need, rumah dapat digolongkan dalam beberapa tingkatan, yaitu:

a. Kebutuhan faal (physiological need), rumah merupakan tempat untuk beristirahat dan kebutuhan dasar kesehatan bagi manusia.

b. Kebutuhan akan keselamatan diri (safety or security need), rumah memberikan perlindungan pada penghuni dan gangguan manusia dan keadaan lingkungan yang tidak diinginkan seperti hujan, sinar matahani, dingin, dan lain-lain.

c. Kebutuhan bersosialisasi (social need), rumah sebagai tempat untuk berinteraksi dengan keluarga dan teman.

d. Kebutuhan akan penghargaan dan penghormatan diri (self esteem or ego need), rumah memberikan status bagi penghuninya.

e. Kebutuhan akan perwujudan diri (self-actualisation needs), rumah bukan hanya sebagai tempat untuk tinggal, tetapi menjadi tempat manusia mengaktualisasikan dirinya.

f. Kebutuhan akan ilmu dan keindahan (cognitive and aesthetic needs), suatu keinginan untuk menerapkan pengetahuan dan memperindah rumahnya.

\section{Konsep Hunian Islami}

Sebagai agama yang sempurna, Islam memiliki konsep ideal dalam semua sisi kehidupan manusia, termasuk tuntunan membangun arsitektur Islami. Dalam buku The Grand Tradition of Islamic Architecture disebutkan bahwa arsitektur Islami adalah seni atau ilmu 
dalam merancang bangunan dengan berlandaskan Al-Qur"an dan Hadits Rasulullah SAW.

Menurut Ahmad Noe"man (2008:5), konsep hunian Islami merupakan konsep hunian yang berlandaskan al-Qur"an dan hadits. Kriteria dari konsep hunian Islami adalah:

1. Keragaman Bentuk
a. Memberikan kebebasan menentukan pilihan kepada calon penghuni akan jenis rumah dan lingkungannya.
b. Alternatif model lingkungan perumahan dan alternatif model rumah.
c. Memberikan kebebasan dan kepuasan kepada perancana dan perancang dalam merealisasikan ide, kreatifitas dan lebih terkonsentrasi pada kapasitasnya.

2. Citra lingkungan yang Islami. Yaitu menampilkan desain yang menunjukkan keislaman, seperti: kaligrafi.

3. Memiliki "sense of direction" terarah pada satu bangunan yang menjadi titik pusat perhatian (focal point) untuk memudahkan arah orientasi mesjid sebagai titik pusat.

4. Adanya pembedaan yang jelas bagi kegiatan kaum pria dan kaum wanita.

5. Terdapat unsur pusat yang didominasi oleh kegiatan beribadah, kegiatan pengembangan kebudayaan dan pendidikan, kegiatan perdagangan dan jasa.

6. Pemukiman harus mampu memberikan kemudahan yang optimal kepada penghuni untuk melakukan berbagai komunikasi, baik dengan sesama manusia, alam, maupun dengan Allah SWT. Dengan asumsi: hubungan dengan tetangga efektif dilakukan dalam bentuk/pola kelompok unit lingkungan skala kecil seperti Rukun Tetangga (RT), adanya mesjid atau mushola untuk kegiatan bersama dalam beribadah dan bermasyarakat, adanya ruang terbuka umum seperti taman-taman, dan terdapat fasilitas perdagangan (warung, kios, dan toko).

7. Konsep grid menghadap kiblat. Penyusunan tata bangunan terutama rumah yang menghadap ke kiblat, sehingga memudahkan orientasi pengaturan mesjid, mushola, dan sholat di ruangan pribadi. (QS. Al-Maidah:97) dan (QS. Al-Baqarah: 148-150)

Bagi setiap muslim, rumah idaman adalah sebuah rumah yang mampu memberikan ketenangan batin dan juga yang bisa membuat penghuninya semakin dekat kepada Allah SWT.(Firstanty \& Hidayat, 2010: 47) 
Di dalam sebuah konsep hunian Islami, adanya hal-hal yang harus diperhatikan yang apabila diterapkan akan menghasilkan nilai-nilai Islami di dalamnya. Konsep tersebut antara lain adalah:

1) Hak Kebebasan Hidup Binatang

Kasih sayang terhadap sesama tidak hanya difokuskan pada menyayangi antar sesama manusia. Sebab, di dunia ini ada juga makhluk lain. Seperti binatang dan tumbuhan yang juga perlu disayangi. Binatang merupakan ciptaan Allah SWT yang berhak mendapatkan kebebasan hidup dan tidak diburu untuk kepentingan pribadi.

Sebuah perumahan Islami akan semakin lengkap dengan adanya binatang-binatang yang dibiarkan hidup sebagaimana mestinya, karena binatang-binatang tersebut bisa meningkatkan keimanan dan rasa syukur kepada Allah SWT. Sesuai dengan hadist riwayat Abu Hurairah ra: "Dari Nabi SAW bahwa pada suatu hari yang sangat panas seorang perempuan pelacur melihat seekor anjing sedang mengelilingi sebuah sumur sambil menjulurkan lidahnya karena kehausan. Ia kemudian melepas sepatu kulitnya (untuk mengambil air sumur yang akan diminumkan kepada anjing), lalu perempuan itu diampuni dosanya"

2) Fasilitas Umum

Tersedianya fasilitas umum di tempat yang tepat dapat menghindarkan seseorang melakukan kegiatan metabolisme secara sembarangan. Karena ada kemungkinan lubang tempat melakukan hajat besar atau kecil tersebut adalah hak makhluk lain. Misalnya, lubang tempat membuang hajat adalah rumah orang lain atau sarang binatang. Selain itu, hal ini dapat menimbulkan sumber penyakit.

3) Lingkungan Sekitar

Pada konsep hunian Islami, memperhatikan aspek lingkungan sekitar merupakan hal terpenting. Karena aspek ini merupakan hajat para penghuni yang akan memilih tinggal di hunian Islami. Hal-hal tersebut antara lain adalah: Jumlah tetangga yang disarankan adalah 40 rumah dari sebelah depan, belakang, kanan, dan kiri. Hadits riwayat AthThahawi mengatakan: "tiap empat puluh rumah adalah tetanggatetangga, (yaitu) yang di depan, di belakang, di sebelah kanan, dan di sebelah kiri (rumahnya)" Mempunyai pusat ibadah, misalnya masjid/mushala yang mudah dijangkau oleh warga serta tempatnya yang strategis. Rasulullah SAW bersabda: "orang yang paling besar pahalanya dalam sholat adalah orang yang paling jauh perjalanan kakinya dan yang lebih jauh lagi dan orang yang menanti shalat sebelum ia shalat berjamaah bersama imam akan mendapatkan pahala yang lebih besar dari orang yang shalat kemudian tidur."(Shahih Muslim no.1064) 
Adanya desain pedestrian dapat membuat penghuni saling menyapa dan mengucapkan salam. Hal ini lebih memiliki unsur Islami yang kuat dibandingkan desain dua buah jalan besar yang hanya diperuntukkan bagi kendaraan.

Keamanan lingkungan dari bahaya kebakaran juga harus diperhatikan.

Sedapat mungkin jalan kompleks tetap dapat dilewati oleh mobil pemadam kebakaran apabila terjadi musibah kebakaran.

Konsep rumah tanpa pagar yang dapat memfasilitasi kegiatan silaturahmi penghuni perumahan, baik tetangga sebelah maupun yang berlalu lalang. Rasulullah SAW bersabda: "Ada lima kewajiban bagi seorang muslim terhadap saudaranya yang muslim; menjawab salam, mendoakan orang yang bersin, memenuhi undangan, menjenguk orang sakit, dan mengiringi jenazah."(Shahih Muslim)"Rasulullah Saw pernah melewati anak-anak lalu beliau mengucapkan salam kepada mereka"(Shahih Muslim)

Konsep rumah yang menghadap kiblat. Dimana arah kiblat condong $21^{\circ}$ sehingga perabot bisa diorientasikan tegak $90^{\circ}$, baik ke arah timur, barat, utara, maupun ke arah selatan karena tidak melawan arah kiblat.

Konsep rumah Islami memang memiliki pangsa pasar tersendiri. Masyarakat yang boleh tinggal di hunian ini diajarkan untuk menanamkan nilai-nilai Islam dan mengamalkan apa yang diajarkan agama Islam. Hal ini terlihat dari sisi arsitektur ataupun aktivitas lingkungan di dalamnya.

Bangunan yang diciptakan mengusung dan menonjolkan nilai-nilai Islam. Terlihat dari bentuk bangunan, transaksi jual beli rumah dan sebagainya. Hal nyata yang akan tampak langsung dari hunian Islami adalah penggunaan kaligrafi pada dinding, peletakan musala di rumah serta tersedianya keran khusus untuk wudhu. Posisi dan tata letak ruangan serta furnitur yang mengikuti aturan agama juga menjadi ciri khas rumah Islami.

Pemilik rumah dengan konsep Islami biasanya membuat ruangan dan bentuk rumah yang bisa menjaga aurat setiap penghuni di dalamnya. Adapun penempatan kloset kamar mandi tidak dibuat mengarah ke kiblat ataupun membelakanginya. Furnitur yang digunakan pun tidak berlebihan dan sederhana.

Selain itu, dalam lingkungan perumahan, hal yang terlihat adalah adanya Taman Pendidikan Al-Quran (TPA), musala atau masjid meski didukung oleh fasilitas lainnya seperti kolam renang atau arena olahraga. Jika pun ada penempatan fasilitas kolam renang, biasanya akan ada pembatas antara kolam renang untuk pria dan wanita ataupun 
penggantian waktu penggunaan kolam.Lingkungan perumahan Islami biasanya menerapkan sistem shalat berjamaah dan melakukan beberapa aktivitas keagamaan lainnya seperti pengajian.

\section{Keputusan Konsumen Muslim dan Maqashid al-Syari'ah}

Keputusan adalah suatu pemilihan tindakan dari dua atau lebih pilihan alternatif. Dengan kata lain, orang yang mengambil keputusan harus mempunyai satu pilihan dari beberapa alternatif yang ada. Bila seseorang dihadapkan pada dua pilihan, yaitu membeli dan tidak membeli, dan kemudian dia memilih membeli, maka dia ada dalam posisi membuat suatu keputusan.(Sudaryono, 2014:208)

Bila ditinjau dari alternatif yang harus dicari, sebetulnya dalam proses pengambilan keputusan, konsumen harus melakukan pemecahan masalah. Suatu masalah timbul dari kebutuhan yang dirasakan dan keinginannya untuk memenuhi kebutuhan dengan konsumsi produk atau jasa yang sesuai. (Sudaryono, 2014:208)

Menurut Nitisusastro (dalam Sudaryono, 2014:3) Konsumen berasal dari bahasa asing (Belanda/Inggris), consumen dan consumer yang arti harfiahnya adalah pembeli. Pengertian lain dari konsumen sangat luas, beragam dan sangat terkait erat dengan tujuan seseorang, membeli suatu produk misalnya sebagai pengguna, yang diterjemahkan dari kata user dari kata Bahasa Inggris. Pengertian lain dari konsumen adalah pemakai, penikmat, pemanfaat, peminum, penerima, dan masih banyak lagi.

Dalam Islam, perilaku seorang konsumen harus mencerminkan hubungan dirinya dengan Allah SWT. Perilaku tersebut tidak di dapati dalam ilmu perilaku konsumsi konvensional. Pada ayat-ayat tertentu, Allah Swt memerintahkan manusia bertindak berdasarkan akal sehat dan perasaan (qalbu) sehat. Setiap perilaku yang dilakukan harus sesuai dengan sasaran untuk membentuk perilaku konsumen Muslim, baik dalam skala individual maupun skala sosial, sesuai dengan ajaran alQur"an dan al-Hadits.

Hingga saat ini, orang berpendapat bahwa kebutuhan pokok manusia terdiri dari pangan, sandang, dan papan. Tanpa terpenuhinya tiga jenis kebutuhan ini manusia tak akan bisa hidup dengan baik. Tetapi, pandangan Islam lebih luas dari sekedar pangan, sandang, dan papan, sebab hal itu hanya terkait dengan urusan duniawi semata.

Menurut Imam al-Syatibi, rumusan kebutuhan manusia dalam Islam terdiri dari tiga jenjang, yaitu:

1. Dharuriyatyang mencakup

a. Agama (din) 


\section{b. Kehidupan (nafs) \\ c. Pendidikan ('aqI) \\ d. Keturunan (nasl), \\ dan \\ e. Harta (mal).}

2. Hajiyat. Jenjang ini merupakan pelengkap yang mengokohkan, menguatkan, dan melindungi jenjang dharuriyat.

3. Tahsiniyat. Jenjang ini merupakan penambah bentuk kesenangan dan keindahan dharuriyat dan hajiyat.

Lima kebutuhan dharuriyat (esensial) yang mencakup din, nafs, „aql, nasl, dan mal merupakan satu kesatuan yang tidak dapat dipisahkan. Bila ada satu jenis yang sengaja diabaikan, akan menimbulkan ketimpangan dalam hidup manusia. Manusia hanya dapat melangsungkan hidupnya dengan baik jika kelima macam kebutuhan itu terpenuhi dengan baik pula yang disering disebut dengan maslahah atau kemaslahatan (Murasa Sarkaniputra, 2002: 11).

Maslahah merupakan konsep terpenting dalam kegiatan dan perilaku ekonomi, baik perilaku konsumen dan produsen. Penerapan teori maslahah dalam perilaku konsumen terlihat dengan jelas pada perbedaan diametral antara keinginan (wants) dan kebutuhan (needs). Wants dan needs berasal dari tempat yang sama, yaitu naluri hasrat manusia. Namun dalam framework Islami, keduanya dibedakan secara diametral. Wants dalam teori ekonomi konvensional muncul dari keinginan naluriah manusia, yang muncul dari konsep bebas nilai (valuefree concept). Ilmu ekonomi konvensional tidak membedakan antara keinginan (syahwat) dan kebutuhan (hajat), karena keduanya memberikan efek yang sama bila tidak terpenuhi, yaitu kelengkaan. Mereka berpenderian bahwa kebutuhan adalah keinginan, demikian pula sebaliknya. (Mingka,2013: 72)

Ketika kebutuhan sesuai dengan maslahah, maka perilaku konsumsi seorang muslim harus mengutamakan mashlahah dharuriyat, seterusnya mashlahah, hajiyat dan tahsiniyat. Kebutuhan yang berada pada tataran maslahah dharuriyat mengacu kepada rumusan dharuriyat, yaitu memenuhi kebutuhan langsung dalam bidang agama, jiwa (pangan, kesehatan, papan), akal (pendidikan), keturunan, dan harta (investasi).

\section{Keputusan Konsumen Muslim dan Maqashid al-Syari'ah}

Dalam perspektif syariah, seorang individu muslim didorong untuk memperoleh barang/jasa yang mengandung kemashlahatan. Barang/jasa dapat diukur tingkat kemashlahatannya relatif pada kemampuan barang/jasa tersebut untuk mengembangkan maslahah. 
Menurut Imam asy-Syatibi, kemashlahatan hanya dapat dicapai dengan memelihara lima unsur pokok kehidupan yaitu agama, jiwa, akal, keturunan dan harta. Seorang muslim akan termotivasi secara keagamaan untuk memperoleh setiap barang dan jasa yang memiliki maslahah tersebut. Dengan demikian, konsep maslahah merupakan konsep yang objektif terhadap perilaku konsumen karena ditentukan oleh tujuan (maqashid) syari"ah.

Dengan beberapa teori tersebut, peneliti bermaksud untuk menganalisa Maqashid al-Syari"ah sebagai dasar keputusan konsumen muslim dalam memilih hunian yang berbasis Islami, dimana di dalam Maqashid al-Syari"ah terdapat unsur- unsur yang berguna bagi kemashlahatan manusia baik di dunia maupun di akhirat. Dengan diciptakannya pemukiman yang berbasis Islami, dapat menjadi pilihan bagi konsumen muslim untuk memiliki hunian yang berlandaskan nilainilai keislaman.

\section{Hasil Penelitian dan Pembahasan}

Deskripsi hasil penelitian merupakan penjelasan tentang gambaran dari masing- masing variabel dalam penelitian. Variabel penelitian ini adalah: Keputusan Konsumen Muslim, Konsep Hunian Islami, dan Maqashid al-Syari"ah yang dihitung menggunakan skor kriterium.

Hasil pengolahan data penelitian Maqashid al-Syari"ah terhadap keputusan konsumen muslim adalah sebagai berikut: tertinggi

$\sum$ skor kriterium $=\sum$ responden $\mathrm{x} \sum$ butir pernyataan $\mathrm{x}$ skor

Kemudian peneliti menggunakan menghitung persentase dari setiap variable. menggunakan rumus berikut: Didapat hasil penghitungan pada tiap variabel adalah:

\begin{tabular}{|c|l|l|}
\hline No & \multicolumn{1}{|c|}{ Variabel } & Skor (\%) \\
\hline 1 & Menjaga Agama (hifdzu-din) & $92,6 \%$ \\
\hline 2 & Menjaga Harta (hifdzu-mal) & $91,3 \%$ \\
\hline 3 & Menjaga Keturunan (hifdzu-nasl) & $89,1 \%$ \\
\hline 4 & Menjaga Pikiran (hifdzu-,,aql) & $88,3 \%$ \\
\hline 5 & Menjaga Jiwa (hifdzu-nafs) & $86,4 \%$ \\
\hline
\end{tabular}

Berdasarkan hasil analisis terhadap hasil pernyataan yang diberikan oleh 40 responden dan juga dilihat dari diagaram tersebut dapat disimpulkan bahwa unsur melindungi agama (hifdzu-din) memiliki peringkat pertama dengan nilai sebesar

92,6\%, kemudian unsur melindungi harta (hifdzu-mal) menduduki peringkat kedua dengan nilai sebesar 91,3\%, unsur melindungi 
keturunan (hifdzu-nasl) menduduki peringkat ketiga dengan nilai sebesar 89,1\%, unsur melindungi pikiran (hifdzu-,,aql) menduduki peringkat ke empat dengan nilai sebesar $88,3 \%$ dan unsur melindungi jiwa (hifdzu-nafs) menduduki peringkat ke lima sebesar $86,4 \%$.

Hasil penelitian ini, secara deskriptif dapat disimpulkan bahwa adanya keterkaitan peranan dari unsur maqashid al-syari"ah sebagai dasar keputusan konsumen muslim memilih hunian Islami. Konsumen muslim yang memilih hunian Islami lebih memilih dari unsur melindungi agama. Hal ini terbukti dari variabel unsur melindungi agama (hifdzudin) yang menduduki peringkat pertama (dengan nilai 92,6\%) dalam keputusan konsumen muslim memilih hunian di Vila Ilhami.

Dilihat dari hasil tersebut, adanya antusias masyarakat muslim yang ingin kembali pada kehidupan yang berlandaskan syariat Islam dalam wujud konsep hunian berbasis Islami. Baik secara lingkungan, fasilitas, program kegiatan, keamanan dan transaksi perdagangan pada lingkungan hunian di Perumahan Vila Ilhami.

\section{Analisa Hasil Penelitian; Konsep hunian Islami}

Analisa penelitian dari studi ini adalah konsep hunian Islami yang berlandaskan pada Al-Qur"an dan hadits, serta didukung teori konsep hunian Islami yang dibuat oleh Noe"man yang meliputi:

a) Citra lingkungan yang Islami, b) Memiliki "sense of direction",

c) Memiliki fasilitas kegiatan beribadah, pengembangan kebudayaan dan pendidikan, kegiatan perdagangan dan jasa.

d) Memiliki RT dan RW

e) Adanya mesjid dan moshola

f) Ruang terbuka umum, seperti: taman

g) Terdapat fasilitas perdagangan, seperti: warung, kios, dan toko

h) Konsep rumah menghadap kiblat, sehingga memudahkan orientasi pengaturan mesjid, mushola, dan sholat di ruangan pribadi.

Dan juga yang terdapat pada teori konsep hunian menurut Firstanty dan Hidayat meliputi:

a) Hak kebebasan hidup binatang b) Terdapat fasilitas umum

c) Jumlah tetangga yang disarankan adalah 40 rumah dari sebelah depan, belakang, kanan dan kiri.

d) Mempunyai pusat ibadah, misalnya mesjid/mushola yang mudah dijangkau oleh warga serta tempatnya yang strategis.

e) Adanya desain pedestrian yang dapat membuat penghuni saling bersilaturahmi dan sebagai akses apabila terjadi kebakaran.

f) Konsep rumah tanpa pagar

g) Konsep rumah yang menghadap kiblat 
Berdasarkan teori yang dibuat oleh Noe"man dan Firstanty tentang konsep hunian Islami, juga hasil observasi yang dilakukan oleh peneliti didapat bahwa PT Mustika Hadiasri selaku developer perumahan Vila Ilhami sudah memenuhi kriteria pemukiman muslim. Penerapanpenerapan yang dilakukan oleh PT. Mustika Hadiasri berlandaskan kaidah-kaidah konsep hunian yang sesuai dengan al-Qur"an serta hadits. Meskipun pihak developer mengakui bahwa mereka masih memiliki banyak kekurangan, tetapi dengan berkembangnya teknologi, pihak developer sampai saat ini terus melakukan pembaharuan terhadap semua fasilititas di Perumahan Vila Ilhami yang nantinya tetap menerapkan unsur-unsur keislaman.

\section{Perilaku konsumen menurut Islam}

Dari hasil responden yang diteliti didapat bahwa perilaku konsumen muslim dalam pengambilan keputusan terkait dengan pada tingkat maslahah, yang merujuk pada pendapat Asy-Syathibi yang dikutip dalam Mingka (2014:74), maslahah merupakan konsep terpenting dalam kegiatan dan perilaku ekonomi, baik perilaku konsumen maupun produsen. Dalam penelitian ini konsep maslahah yang berkaitan dengan keputusan konsumen adalah maslahah dharuriyah, maslahah hajiyah, maslahah tahsiniyah. Penelitian pada studi ini ditemukan bahwa konsumen Vila Ilhami mengambil keputusan berdasarkan mashlalah dharuriyat. Yang mayoritas dari mereka memilih hunian Islami dikarenakan ingin menjaga agama (din), menjaga jiwa (nafs), menjaga pikiran („aql), menjaga keturunan (nasl), dan harta (mal), dimana unsur-unsur tersebut termasuk pada mashlahah dharuriyat. Seperti yang dingkap oleh Imam Syathibi, kemashlahatan hanya dapat dicapai apabila menjaga lima unsur pokok tersebut. Seorang konsumen muslim, akan termotivasi secara keagamaan untuk memperoleh setiap barang dan jasa yang memiliki mashlahah. Karena kemashlahatan manusia mencakup kehidupan dunia dan akhirat.

\section{Peran Maqashid al-Syariah Sebagai Dasar Keputusan}

Pembahasan maqashid al-syariah oleh Imam Syathibi dan didukung oleh hasil penelitian ini, menunjukkan bahwa peranan dari maqasid alsyariah dalam perilaku keputusan konsumen sangat berperan besar. Hal ini terlihat pada hasil kuesioner responden di Vila Ilhami yang mencakup unsur dari maqashid al- syari"ah meliputi:

1. Menjaga agama ( hifdzu-din) sebesar 92,6\%, yang meliputi:

a) perumahan Vila Ilhami memiliki mesjid raya yang bisa menfasilitasi penghuni untuk menunaikan sholat lima waktu. 
b) Perumahan Vila Ilhami menyediakan mushola pada setiap cluster. c) Adanya tenaga pendidik Qur"an (ustadz)

d) Adanya himbauan untuk melakukan sholat berjamaah

e) Terdapat sarana berupa kajian-kajian Islami

2. Menjaga harta (hifdzu-mal) sebesar 91,3\%, meliputi:

a) perumahan Vila Ilhami menyediakan sarana bagi penghuni untuk menyalurkan Zakat, Infak, Sedekah, dan Wakaf pada masing-masing mushola/mesjid.

b) Adanya himbauan bagi tamu yang bukan penghuni untuk melapor ke keamanan setempat dalam waktu $1 \times 24$ jam.

c) Sistem keamanan yang 24 jam.

d) Kerjasama dengan pihak terkait (polisi) dalam hal tindakan pencurian. e) Tersedia Bank Syariah untuk membantu penghuni melakukan transaksi sesuai syariah.

3. Menjaga keturunan (hifdzu-nasl) sebesar 88,3\%, meliputi:

a) perumahan Vila Ilhami memiliki pedestrian yang berfungsi sebagai akses menuju mushola/mesjid dan akses apabila terjadi kebakaran.

b) Tersedia lembaga legalisasi perkawinan berupa Kantor Urusan Agama (KUA)

c) Adanya himbauan bagi penghuni untuk tidak melakukan aktivitas yang berhubungan dengan zina.

d) Adanya sanksi bagi warga yang melakukan zina

e) Perumahan Vila Ilhami menyediakan kamar tidur terpisah bagi anak laki-laki dan anak perempuan pada konsep hunian.

4. Menjaga akal (hifdzu-,,aqI) sebesar 88,3\%, yang meliputi:

a) Perumahan Vila Ilhami menyediakan lembaga pendidikan formal dan non-formal.

b) Adanya larangan bagi penghuni untuk menjalankan bisnis haram seperti minuman keras, narkotika, dan obat terlarang.

c) RT dan RW yang berfungsi sebagai wadah penyampaian pendapat warga.

d) Larangan bagi penghuni untuk mengkonsumsi narkotika dan obat terlarang.

e) Adanya kerjasama dengan pihak terkait (polisi) dalam hal pemberian sanksi bagi penghuni yang mengedarkan / mengkonsumsi narkoba.

5. Menjaga jiwa (hifdzu-nafs) sebesar 86,4\%, yang meliputi:

a) perumahan Vila Ilhami menerapkan sistem keamanan 24 jam untuk penghuni.

b) perumahan Vila Ilhami menyediakan fasilitas kesehatan berupa rumah sakit dan klinik berbasis Islami. 
c) Tersedia balai warga untuk mendukung aktifitas pertemuan dan bermasyarakat.

d) Kerjasama dengan pihak terkait (polisi) apabila terjadi tindak pidana pembunuhan.

e) Kegiatan gotong royong untuk menjaga kesehatan lingkungan.

Dengan seiringnya perkembangan tingkat permintaan hunian dan teknologi, Perumahan Vila Ilhami mengalami pergeseran dan perubahan pada beberapa aspek konsep hunian Islami yang diterapkan. Misalnya pada saat ini terdapat beberapa rumah yang menggunakan pagar. Hal ini sebagai antisipasi untuk menjaga anak-anak yang keluar rumah tanpa sepengetahuan penghuni rumah. Melihat situasi dari Perumahan Vila Ilhami sendiri yang sudah ramai dan hampir semua penghuni memiiki kendaraan yang berakibat pada keselamatan anak-anak, terutama anakanak kecil yang masih belum mengerti tentang keselamatan. Juga karena keinginan penghuni itu sendiri untuk memagarkan rumahnya terkait untuk menjaga keindahan rumah mereka keselamatan anak-anak mereka.

Akses jalan raya pada kawasan Vila Ilhami saat ini sudah mulai padat. Banyak kendaraan yang bukan penghuni melintasi area Islamic Village. Sebagai antisipasi, pihak yayasan dan developer menerapkan sistem sticker pada kendaraan yang dimiliki penghuni. Sticker tersebut berguna untuk mengurangi kendaraan umum yang masuk ke wilayah Komplek Islamic Village dan Vila Ilhami. Apabila terdapat kendaraan yang tidak memiliki sticker ingin masuk atau melintas di kawasan Islamic Village, maka akan dikenakan biaya karcis masuk perumahan sebesar Rp 2000 (dua ribu rupiah) sampai Rp 10000 (sepuluh ribu rupiah). Faktor lain, pihak developer belum mengizinkan apabila akses jalan raya diserahkan ke Pemerintah Daerah karena developer sendiri masih memiliki proyek perumahan yang belum selesai, terutama proyek perumahan yang berbentuk kavling.

Berdasarkan hasil penelitian yang sudah diolah oleh peneliti, bahwa hasil penelitian ini sudah mendapat persetujuan dari beberapa pihak dan juga dari pihak developer PT. Mustika Hadiasri selaku pengembang dari Perumahan Vila Ilhami Tangerang. Hal ini untuk memenuhi kriteria konfirmabilitas (confirmability) dan memastikan bahwa penelitian ini telah objektif dan valid.

\section{Kesimpulan}

Penelitian ini bertujuan untuk mengetahui seberapa besar peran dari Maqashid al-Syari"ah terhadap keputusan konsumen muslim dalam memilih hunian pada Perumahan Vila Ilhami Tangerang. Dari hasil 
penelitian yang dilakukan terhadap PT Mustika Hadiasri selaku pengembang Perumahan Vila Ilhami Tangerang, dapat disimpulkan sebagai berikut:

1. Karakteristik sebuah hunian Islami merupakan konsep hunian yang berlandaskan Al- Qur"an dan Hadits disamping menerapkan desain yang mengacu pada arsitektur Arab maupun Timur Tengah dan dekorasi motif Islami, lebih diutamakan adanya tujuan syariat Islam di dalamnya.

2. Dalam hal pengambilan keputusan, seorang konsumen muslim harus mengutamakan mashlahah dharuriyat, yang selanjutnya mashlahah hajiyat dan mashlahah tahsiniyat. Mashlahah dharuriyat mengacu kepada rumusan dharuriyat, yaitu memenuhi kebutuhan langsung dalam unsur agama, jiwa (pangan, kesehatan, papan), akal (pendidikan), keturunan, dan harta (investasi), yang dikategorikan dalam Maqashid al-Syari"ah.

3. Analisis Maqashid al-Syari"ah dalam keputusan konsumen muslim memilih hunian Islami pada Perumahan Vila Ilhami adalah terlihat pada hasil penelitian ini yang mencakup pada unsur yang lebih berperan besar yaitu menjaga agama (hifdzu-din) sebesar 92,6\%, menjaga harta (hifdzu-mal) sebesar 91,3\%, menjaga keturunan (hifdzunasl) sebesar 89,1\%, menjaga pikiran (hifdzu-aql) sebesar 88,3\%, dan yang terakhir adalah menjaga jiwa (hifdzu-nafs) sebesar $86,4 \%$.

\section{Daftar Pustaka}

Al-Qur'an dan Terjemah, Mushaf Al-Azhar, Bandung: Penerbit Hilal, 2010 Abdullah, Fikih Hadits Bukhari-Muslim, Jakarta: Ummul Qura, 2013, Cet. ke-1

Abdurrahman, HRD Syariah: Teori dan Implementasi, Jakarta: PT. Gramedia Pustaka Utama, 2014

Auda, Jasser. Membumikan Hukum Islam Melalui Maqashid Syari"ah, Bandung: Mizan Media Utama, 2015, Cet. 1

Chan, Arianis, Agustus 2010. "Pengaruh Ekuitas Merek Terhadap Proses

Keputusan Pembelian Konsumen: Studi Kasus Bank Muamalat Cabang Bandung". FISIP Universitas Parahyangan. Vol. 6, No. 1

Creswell, J.W., Research Design: Qualitative, Quantitative, and Mixed Methods Approaches. California: SAGE Publications, Inc, 2002

Effendy, Satria. Ushul Fiqh, Jakarta: Kencana Prenada Media Group, 2009. Cet. ke-3

Firstanty, Anddys dan Ade Hidayat, 31 Inspirasi Rumah Islami, Jakarta: TransMedia, 2010, Cet.1 
Hadi, Kuncoro, Maret 2012, "Implementasi Maqashid Syariah Sebagai Indikator Perusahaan Islami". Fakultas Ekonomi Universitas Al Azhar Indonesia. Vol. 1, No. 3

Harisadono, Sutrisno. Statistik Ekonomi II, Serang Banten: CV Cahaya Minolta, 2012, Cet. ke-1

Mingka, Agustianto. Maqashid Syariah Dalam Ekonomi dan Keuangan Syariah, Jakarta: Iqtishad Publishing, 2013

Moleong, Lexy J. Metodologi Penelitian Kualitatif, Bandung: PT. Remaja Rosdakarya, 2011, Cet. ke-29

Murwanti, Sri, Juni 2009, "Perilaku Konsumen Dalam Memilih Perumahan Pada Perumahan Cipta Laras Bulusulur Wonogiri", Fakultas Ekonomi Universitas Muhammadiyah Surakarta, Volume 13, No. 1

Muzlifah, Eva, 2013, "Maqashid Syariah Sebagai Paradigma Dasar Ekonomi Islam". STAI Darul Ulum Banyuwangi. Vol. 3, No. 2

Noe"man, Ahmad. Bahan Ajar: Konsep Penataan Ruang Pemukiman Islami, Bandung: Universitas Islam Bandung, 2008

Sahroni, Oni dan Adiwarman Karim, Maqashid Bisnis dan Keuangan Islam, Jakarta: PT. Rajagrafindo Persada, 2015, Cet. ke-1

Shidiq, Buku Ajar: Ushul Fiqh, Jakarta: UIN Syarif Hidayatullah, 2010 www.agenpropertisyariah.com (diakses tanggal 8 Juni 2016) www.developerpropertisyariah.com (diakses tanggal 11 Juni 2016) www.islamicvillage.sch.id (diakses tanggal 20 Juni 2016) www.urbanindo.com (diakses tanggal 24 Juni 2016)

Yunia, Ika dan Abul Kadir, Prinsip Dasar Ekonomi Islam: Perspektif Maqashid al- Syari"ah, Jakarta: Kencana Prenada Group, 2015, Cet. ke-2

Zahra, Abu. Ushul Fiqh, Jakarta: Pustaka Firdaus, 2000, Cet. ke-6 